\title{
Intake, performance, carcass traits and meat quality of goats grazing in the Caatinga rangeland
}

\section{Consumo, desempenho, características de carcaça e qualidade da carne de caprinos criados em pastejo na Caatinga}

\author{
Dulciene Karla de Andrade Silva ${ }^{1}$; Fábia Simone Bezerra Cordeiro²; \\ Érica Carla Lopes da Silva ${ }^{3}$; Daniel Barros Cardoso ${ }^{4 *}$; André Luiz Rodrigues \\ Magalhães ${ }^{1}$; Airon Aparecido Silva de Melo ${ }^{1}$; Kedes Paulo Pereira ${ }^{5}$; \\ Evannielly Thuanny dos Santos Silva ${ }^{2}$
}

\section{Highlights:}

Spineless cactus provided higher supplement intake for grazing goats.

Supplements based on spineless cactus provided greater non-fibrous carbohydrates intake.

The highest CP intake occurred in goats supplemented with mororó hay associated with spineless cactus.

Food supplementation did not influence goat meat quality.

\begin{abstract}
The objective of this study was to evaluate the intake, performance, carcass characteristics, and meat quality of goats submitted to grazing in the Caatinga rangeland supplemented with two hays: jitirana (Merremia aegyptia) or mororó (Bauhinia cheilanta), with or without the association of spineless cactus (Nopalea cochelinifera Salm Dick), and a treatment without supplementation (control). Thirty male goats (castrated), of no defined breed, with an initial mean body weight of $19 \pm 0.35 \mathrm{~kg}$ and approximately 90 days of age were used. The experimental design was completely randomized, using initial body weight as a covariate, in a factorial design $(2 \times 2)+1$, with five treatments and six replicates. The highest intake of supplement, total dry matter (DM), non-fiber carbohydrates (NFC), and total digestible nutrients (TDN) intakes occurred in the animals supplemented with jitirana or mororo hays associated with spineless cactus, and higher crude protein (CP) intake accounted for goats supplemented with mororó hay and spineless cactus. Higher intakes of neutral detergent fiber (NDF) were observed in the animals fed with jitirana hay. There were no dietary influences in pasture DM intake, performance, cut weights, and carcass characteristics. As for the quality of the meat, there was an influence of the treatments only on the parameter $b^{*}$ (yellowness). Feeding supplementation with jitirana and mororó hays, and spineless cactus did not improve performance and carcass characteristics, and did not negatively influence the quality of goat meat raised on pasture in the Caatinga region.
\end{abstract}

Key words: Biome. CCI. Roughage. Supply. Small Ruminant.

\footnotetext{
1 Profs. Drs., Universidade Federal do Agreste de Pernambuco, UFAPE, Garanhuns, PE, Brasil. E-mail: kakazoo50@gmail.com; andre30036@gmail.com; aironuag@hotmail.com

2 Discentes, Curso de Mestrado do Programa de Pós-Graduação em Ciência Animal e Pastagem, UFAPE, Garanhuns, PE, Brasil. E-mail: fabiasimone 3@hotmail.com; evanniellysilva@hotmail.com

3 Bolsista do Programa Nacional de Pós-Doutorado, PNPD, Departamento de Zootecnia, Universidade Federal Rural de Pernambuco, UFRPE, Recife, PE, Brasil. E-mail: ericarlalopes@gmail.com

4 Bolsista do Programa Nacional de Pós-Doutorado, PNPD, UFAPE, Garanhuns, PE, Brasil. E-mail: danbarrc@hotmail.com

5 Prof. Dr., Centro de Ciências Agrárias, Universidade Federal de Alagoas, UFAL, Rio Largo, AL, Brasil. E-mail: kedesp@ hotmail.com
}

* Author for correspondence 


\title{
Resumo
}

\begin{abstract}
Objetivou-se com este estudo avaliar o consumo, desempenho, características de carcaça e a qualidade da carne de caprinos criados em pastejo na Caatinga e suplementados com dois tipos de fenos: jitirana (Merremia aegyptia) ou mororó (Bauhinia cheilanta), com ou sem a associação a palma forrageira (Nopalea cochelinifera Salm Dick), e um tratamento sem suplementação (controle). Foram utilizados 30 caprinos machos castrados, sem padrão racial definido, com peso corporal inicial de $19 \pm 0,35$ $\mathrm{kg}$ e aproximadamente 90 dias de idade. O delineamento experimental utilizado foi o inteiramente casualizado, usando o peso corporal inicial como covariável, em arranjo fatorial $(2 \times 2)+1$, com cinco tratamentos e seis repetições. Os maiores consumos de suplemento, consumo total de matéria seca (MS), carboidratos não fibrosos (CNF) e dos nutrientes digestíveis totais (NDT) ocorreram para os animais alimentados com feno de jitirana ou mororó associados à palma forrageira, e maior consumo de proteína bruta $(\mathrm{PB})$ ocorreu pelos caprinos suplementados com o feno de mororó com palma forrageira. Maiores consumos de fibra em detergente neutro (FDN) foram observados nos animais suplementados com feno de jitirana. Não houve influência das dietas sobre o consumo de MS do pasto, desempenho, pesos dos corte e as características de carcaça. Quanto a qualidade da carne, houve influencia dos tratamentos apenas sobre o parâmetro b* (Intensidade de amarelo). A suplementação alimentar com os fenos de jitirana e mororó, e palma forrageira não proporcionou melhorias no desempenho e nas características de carcaça, bem como não influenciou negativamente a qualidade da carne de caprinos criados em pastejo em região de Caatinga.
\end{abstract}

Palavras-chave: Bioma. ICC. Pequenos ruminantes. Suplementação. Volumoso.

\section{Introduction}

Goat breeding in semi-arid regions is an important source of income for the populations living in these areas through the production of meat and milk, constituting an important source of protein of high biological value. However, in these regions rainfall is scarce or poorly distributed, which compromises the production of food for the maintenance of herds. Due to the temporal and spatial irregularity of the rains, the forage supply is not constant throughout the year.

In these conditions is the Brazilian Caatinga biome in which the greatest availability of forage occurs in the rainy season, consisting of the herbaceous stratum, and as the dry season is characterized, the senescent leaves of woody plants are incorporated into the animals' diet and may represent the only available forage resource (Pereira, Silva, \& Cézar, 2013). Thus, conservation in the form of hay or silage of the eventual surplus produced during the precipitation pulses ensures forage supply for times of scarcity, improving the productive indices.
The use of native plants or those adapted to the semi-arid regions, which are more efficient in the use of water, conserved in the form of hay or silage, is a way of guaranteeing food supply for the most critical periods and reducing production costs (Abdalla et al., 2017; Gusha, Halimani, Katsande, \& Zvinorova, 2015).

Native plants from the Caatinga have potential for feeding ruminants, according to the available forage supply (Pinto et al., 2019), as well as their chemical composition, in which the leaves of the herbaceous and tree extract present values of crude protein from 162.5 to $169.6 \mathrm{~g} \mathrm{~kg} \mathrm{DM}^{-1}$ (M. J. S. Silva et al., 2017), and specifically in the case of mororó (Bauhinia cheilanta Bong Stend) and jitirana (Merremia aegyptia L. Urban) with crude protein values of 115.0 to $171.9 \mathrm{~g} \mathrm{~kg} \mathrm{DM}^{-1}$ (Lacerda, Silva, Linhares, Maracajá, \& Pinto, 2015; Santos et al., 2017). Associated with these, spineless cactus (Opuntia or Nopalea) can be used, which has a high concentration of non-fibrous carbohydrates $(547 \mathrm{~g}$ $\mathrm{kg} \mathrm{DM}^{-1}$ ), total carbohydrates (834 $\left.\mathrm{g} \mathrm{kg} \mathrm{DM}^{-1}\right)$, and dry matter digestibility $\left(676 \mathrm{~g} \mathrm{~kg} \mathrm{DM}^{-1}\right)$. 
In view of this, the use of supplementation with native forage and spineless cactus during the dry period may supply part of the necessary nutrients for animals, contributing to better productive responses. The evaluation of animal performance as well as carcass characteristics and meat quality is a way of measuring the potential of diets or production systems and, in turn, meeting the market demand for quality carcasses. The use of spineless cactus exclusively or associated with other native forage plants as a dietary supplement for goats grazing in semi-arid areas has presented different responses regarding nutrient intake, carcass characteristics, and meat quality (Bezerra et al., 2012; Gusha et al., 2015; D. C. Silva et al., 2016).

The objective of this study was to evaluate nutrient intake, performance, carcass characteristics, and meat quality of goats raised on pasture in the Caatinga and supplemented with hays from native forage plants (jitirana or mororó), associated or not with spineless cactus.

\section{Materials and Methods}

The handling and care of the animals were in accordance with the guidelines and recommendations of the Ethics Committee on the Use of Animals (CEUA) at UFRPE, under license number (104/2014).

The experiment was conducted at the Instituto Agronômico de Pernambuco (IPA), located in the city of Sertânia, whose geographic position coordinates are: latitude $08^{\circ} 04^{\prime} 25^{\prime \prime}$ south and longitude $37^{\circ} 15^{\prime}$ 52", in the Sertão do Moxotó microregion, $600 \mathrm{~m}$ above sea level, in a Caatinga ecosystem with a regional semi-arid hot climate. The average rainfall in the experimental period was $107.5 \mathrm{~mm} \mathrm{month}^{-1}$.

Thirty castrated male goats of no defined breed were used, with an initial body weight of $19 \pm 0.35 \mathrm{~kg}$ and approximately 90 days of age. At the beginning of the experiment, all animals were weighed, identified, treated against endo and ectoparasites. The experimental period lasted 105 days, with 15 days to adapt to the experimental conditions.

The animals were allocated to five treatments: grazing without supplementation (WS); supplemented with jitirana hay (Merremia aegyptia L. Urban) (JH); mororó hay (Bauhinia cheilanta Bong Stend) (MH); jitirana hay + spineless cactus (Nopalea cochelinifera Salm Dick) (JH $+\mathrm{SC})$; and mororó hay + spineless cactus $(\mathrm{MH}+\mathrm{SC})($ Table 1$)$.

Table 1

Chemical composition of foods and experimental diets

\begin{tabular}{|c|c|c|c|c|c|c|c|c|}
\hline \multirow{2}{*}{ Nutrients } & \multirow{2}{*}{$\underset{\text { (extrusa) }}{\mathrm{G}}$} & \multirow{2}{*}{$\begin{array}{c}\text { Jitirana } \\
\text { hay }\end{array}$} & \multirow{2}{*}{$\begin{array}{c}\text { Mororó } \\
\text { hay }\end{array}$} & \multirow{2}{*}{$\begin{array}{l}\text { Spineless } \\
\text { cactus }\end{array}$} & \multicolumn{4}{|c|}{ Diets } \\
\hline & & & & & $\mathrm{JH}$ & $\mathrm{MH}$ & $\mathrm{JH}+\mathrm{SC}$ & $\mathrm{MH}+\mathrm{SC}$ \\
\hline $\mathrm{DM}\left(\mathrm{g} \mathrm{kg} \mathrm{NM}^{-1}\right)$ & 135.4 & 837.6 & 844.1 & 135.6 & 115.4 & 116.0 & 150.7 & 140.0 \\
\hline $\mathrm{OM}^{1}$ & 863.0 & 893.7 & 898.8 & 870.9 & 695.4 & 670.4 & 714.3 & 693.5 \\
\hline $\mathrm{Ash}^{1}$ & 136.9 & 106.2 & 101.1 & 129.1 & 110.0 & 106.2 & 111.0 & 109.2 \\
\hline $\mathrm{CP}^{1}$ & 152.9 & 86.6 & 106.6 & 39.3 & 112.5 & 118.0 & 118.1 & 117.0 \\
\hline $\mathrm{EE}^{1}$ & 33.6 & 17.8 & 24.7 & 15.4 & 26.9 & 25.9 & 26.1 & 25.9 \\
\hline $\mathrm{NDF}^{1}$ & 617.0 & 625.8 & 601.2 & 302.1 & 497.0 & 478.7 & 497.5 & 484.1 \\
\hline $\mathrm{ADF}^{1}$ & 490.2 & 369.9 & 491.7 & 182.5 & 393.7 & 380.5 & 385.9 & 383.5 \\
\hline $\mathrm{TC}^{1}$ & 676.3 & 789.9 & 769.2 & 816.4 & 545.8 & 526.4 & 569.8 & 550.5 \\
\hline $\mathrm{NFC}^{1}$ & 59.3 & 164.1 & 168.0 & 514.3 & 48.7 & 47.7 & 72.3 & 66.4 \\
\hline IVDMD ( g kg DM $\left.^{-1}\right)$ & 553.4 & 512.3 & 435.8 & 787.2 & 0.45 & 0.43 & 0.46 & 0.45 \\
\hline
\end{tabular}

${ }^{1} \mathrm{~g} \mathrm{~kg} \mathrm{DM}^{-1} ; \mathrm{G}=$ grazing without supplementation; $\mathrm{JH}=$ jitirana hay; $\mathrm{MH}=$ mororó hay; $\mathrm{JH}+\mathrm{SC}=51 \%$ of jitirana hay $+49 \%$ of spineless cactus; $\mathrm{MH}+\mathrm{SC}=51 \%$ of mororó hay $+49 \%$ of spineless cactus; $\mathrm{DM}=$ dry matter; $\mathrm{NM}=$ natural matter; OM $=$ organic matter; $\mathrm{CP}=$ crude protein; $\mathrm{EE}=$ ether extract; $\mathrm{NDF}=$ neutral detergent fiber; $\mathrm{ADF}=$ acid detergent fiber; NFC $=$ non-fibrous carbohydrates; $\mathrm{TC}=$ total carbohydrates; $\mathrm{IVDMD}=$ in vitro dry matter digestibility $\left(\mathrm{g} \mathrm{g} \mathrm{DM}^{-1}\right)$. 
The pasture comprised an area of Caatinga corresponding to 37 ha. The animals remained in the grazing area from 6:00 am to 4:00 pm, and after that period were collected at the management center. The animals of the WS treatment were collected in a collective stall, provided with a collective salt and water trough and the animals that received supplementation were collected in individual stalls measuring $2.1 \times 1.5 \mathrm{~m}$, equipped with individual salt and water troughs.

The supplements were composed of 59\% hay (jitirana or mororó) and $41 \%$ spineless cactus based on dry matter, and $10 \mathrm{~g}$ of mineral salt mixed with supplementation, mixed daily. Previously, supplementation was stipulated at $1 \%$ of the animals' initial body weight. However, during the adaptation period, it was observed that the animals were not consuming the supplements in the amount previously stipulated, therefore, all animals received $0.5 \%$ of body weight until the end of the experiment.

In another experiment, carried out during the same experimental period and in the same area, the composition of the samples referring to the pasture was determined using extrusion collection, divided between the morning (8:00 am) and afternoon $(14: 00 \mathrm{pm})$, on alternate days, in order to reduce possible effects of the extrusion collection on the consumption behavior of the animals, which was carried out on six goats of no defined breed, fistulated in the rumen, with a body weight of approximately $25 \mathrm{~kg}$, for five consecutive days in five subperiods of 21 days. For the extrusion collection, all rumen contents were removed and stored in buckets, duly identified by animal. Then, the animals were released into the experimental area for 40 minutes. After this period, they were collected to collect the extrusion, which in turn was packed in plastic bags, duly identified, and frozen.

Samples of the food supplied (spineless cactus, jitirana hay, mororó hay), leftovers, and pasture (extrusa) were collected, weighed, identified, and stored at $-20{ }^{\circ} \mathrm{C}$. At the end of each subperiod, a composite sample was formed for chemical analysis of the ingredients. The samples were pre-dried in a forced ventilation oven at $55{ }^{\circ} \mathrm{C}$ for a period of approximately 72 hours. Then, they were ground in a Willey mill in $1 \mathrm{~mm}$ sieves and packed in polyethylene bottles, identified, and hermetically sealed for chemical analysis.

The contents of dry matter, organic matter, crude protein, and ether extract were determined, according to the methodology described by the Association of Official Analytical Chemists [AOAC] (1997). The determination of neutral detergent fiber (NDF) and acid detergent fiber (ADF) was carried out according to the method proposed by Van Soest, Robertson and Lewis (1991), using the Tecnal DD-140 device.

Total carbohydrates (TC) were estimated using the equation described by Sniffen, O'Connor, Van Soest, Fox and Russell (1992): TC $=100-(\% \mathrm{CP}+$ $\% \mathrm{EE}+\%$ ash). To obtain non-fibrous carbohydrates (NFC), the equation described by Hall, Hoover, Jennings and Webster (1999), where NFC $=\%$ TC $-\%$ NDF was used.

The intake of dry matter in the pasture was estimated through the relationship between the production of fecal dry matter and the indigestibility of dry matter:

$$
\text { DMIpasture }(\mathrm{kg})=\frac{\text { FDMP }(\mathrm{kg}) \mathrm{x} \text { ind. DMfecal }}{\text { ind. DMpasture }}
$$

Where, DMI = dry material intake; FDMP = fecal dry matter production; ind = indigestibility; and $\mathrm{DM}=$ dry matter.

The fecal dry matter production (FDMP) was estimated using daily single doses of $0.250 \mathrm{mg}$ of the external indicator LIPE ${ }^{\circledR}$ (hydroxyphenylpropane), offered to all experimental animals, during the same extrusion collection period, the last five days of each subperiod (from the 16th day), and the feces were collected in the days following the indicator supply, directly from the second rectal ampoule (Saliba et al., 2015), and then stored in a freezer at $-20^{\circ} \mathrm{C}$. 
The fecal samples corresponding to each animal were homogenized, constituting a composite sample. Then, they were pre-dried, ground, and packed in labeled bottles and sent to the Chemistry Department of the Institute of Exact Sciences (ICEX) of the Federal University of Minas Gerais (UFMG) for estimates of fecal production by LIPE® through of an infrared spectrometer, where the determination of the hydroxyphenylpropane content in feces was performed. To determine the FDMP estimate of each animal, the following equation was used:

$\mathrm{X}=$ (Amount of $\mathrm{LIPE}^{\circledR}$ administered/LIPE ${ }^{\circledR}$ concentration in feces) $* 100$

After 105 days of experimental period, the animals were weighed (final weight) and subjected to a solid fasting for approximately $16 \mathrm{~h}$. After that time, the animals were weighed again to obtain body weight at slaughter (BWS).

Subsequently, the animals were stunned with a penetrating captive bolt pistol, followed by bleeding for approximately four minutes, through the carotid and jugular sections, according to the Normative Instruction $n^{\circ} 3$ (Instrução Normativa n. 3; de 17 de Janeiro de 2000). Skinning and evisceration were performed, the head and feet were removed to record the hot carcass weight (HCW), keeping the kidneys and pelvic-renal fat. The gastrointestinal tract was weighed full and empty, quantifying of the gastrointestinal tract content (GITC) to determine the empty body weight of (EBW) and also calculating the hot carcass yield (HCY) according to the following formulas: $\mathrm{EBW}=\mathrm{BWS}-\mathrm{GITC}$ and $\mathrm{HCY} \%=\mathrm{HCW} / \mathrm{BWS} \times 100$.

The carcasses were cooled for 24 hours in a cold room at approximately $4{ }^{\circ} \mathrm{C}$. After this period, the $\mathrm{pH}$ of the carcasses was evaluated 24 hours postmortem, in the Semimembranosus muscle, using a $\mathrm{pH}$ meter equipped with a penetrating electrode (Testo 205). Subsequently, these were weighed to obtain the cold carcass weight $(\mathrm{CCW})$, and the cold carcass yield (CCY) and biological yield (BY) were also calculated: $\mathrm{CCY} \%=\mathrm{CCW} / \mathrm{BWS} \times 100$ and $\mathrm{BY}(\%)=\mathrm{CCW} / \mathrm{EBW} \times 100$ and the cooling losses $\mathrm{CL} \%=((\mathrm{HCW}-\mathrm{CCW}) / \mathrm{HCW}) \times 100$.

After weighing to determine the $\mathrm{CCW}$, the carcasses were evaluated subjectively to determine the degree of conformation and finishing. In addition, morphometric measurements were performed and the carcass compactness index (CCI) was also calculated, determined by the following formula: CCI $\left(\mathrm{kg} \mathrm{cm}^{-1}\right)=\mathrm{CCW} /$ Internal carcass length, according to Cezar and Souza (2007).

In the evaluation of the carcass after removing the tail, the half-carcasses were divided into six anatomical regions (neck, shoulder, rib, saw, loin, and leg). Then, to measure the longissimus muscle area (LMA), a cross-section between the 12th and 13th thoracic vertebrae was performed in the left half carcass. After exposing the Longissimus lumborum muscle, a transparent plastic film was placed on it and, with the aid of an appropriate pen, the muscle outline was traced for later LMA measurement using a digital planimeter.

In the physical-chemical analyses of the meat, the left loins (Longissimus lumborum) were used, which were previously thawed in a cold room for 24 hours at $4{ }^{\circ} \mathrm{C}$. For color evaluation, readings were performed using a colorimeter (Minolta Chroma Meter CR-400), which was positioned directly on the muscle surface, at three different points, after exposure to oxygen for 50 minutes. The evaluated parameters consisted of lightness $\left(\mathrm{L}^{*}\right)$, redness $\left(\mathrm{a}^{*}\right)$, and yellowness $\left(b^{*}\right)$.

To determine cooking losses, two $2.54 \mathrm{~cm}$ thick Longissimus lumborum steaks were weighed and roasted in an electric oven preheated to $150^{\circ} \mathrm{C}$, until the internal temperature of the samples reached the limit of $71^{\circ} \mathrm{C}$. Then, after cooling, the samples were weighed to obtain the weight loss expressed as a percentage, according to Wheeler, Cundiff and Koch (1993). 
The shear force analysis was performed using the steaks after determining the cooking losses, to which at least three cylinders were removed in the direction of the muscle fibers, with a $1.27 \mathrm{~cm}$ diameter pourer. The shear force was measured using the Warner-Bratzler shear machine (G-R Manufacturing CO., Model 3000) (Wheeler et al., 1993).

The experimental design used was completely randomized, using the initial body weight as a covariate, in a factorial design $(2 \times 2)+1$, two hays (Jitirana and Mororó), with and without the addition of spineless cactus, plus a control treatment (pasture without supplementation), composing five treatments and six repetitions, using the following model:

$$
Y i j k=\mu+H i+S C j+\left(H^{*} S C\right) i j+\beta(X i j-X)+e i j k
$$

Where, Yijk $=$ observed value of the dependent; $\mu$ = general mean; $H i=$ hay type effect $i ; S C j=$ with or without spineless cactus $j$; $\left(H^{*} S C\right) i j=$ effect of the interaction of the type of hay $i \mathrm{x}$ with or without spineless cactus $J ; \beta(X i j-X)=$ effect of the covariate (initial body weight); eij = experimental error. The data were submitted to analysis of variance and the means were compared with Tukey's test and, with the control treatment, with the Dunnett test, at 5\% significance, using the Statistical Analysis System Institute [SAS Institute] (2003).

\section{Results and Discussion}

The intakes of supplements, total dry matter (DM), crude protein (CP), non-fibrous carbohydrates (NFC), and total digestible nutrients (TDN) $\left(\mathrm{g} \mathrm{day}^{-1}\right)$ by goats grazing in the Caatinga differed from the control treatment (without supplementation) $(\mathrm{P}<0.05)$, with higher values observed for supplements formed by jitirana or mororó hays associated with spineless cactus (Table 2 ). The treatments composed of spineless cactus were consumed more than the others, probably due to the good palatability of this food and to the higher levels of non-fibrous carbohydrates (NFC), since this fraction involves rapid ruminal degradation and increased passage rate (Siqueira et al., 2017). On the other hand, the total DM intake was influenced by the intake of supplements, which in average values corresponded to 0.038 and $0.075 \%$ of body weight (BW) for those that contained only the jitirana and mororó hays and 0.39 and $0,37 \%$ of the $\mathrm{CP}$ for supplements containing spineless cactus.

Regarding the intake of neutral detergent fiber (NDF), it differed from the control treatment $(\mathrm{P}<0.05)$ only when the animals were supplemented with jitirana hay, which showed a higher value, followed by mororó hay (Table 2). In this experiment, differences were observed varying from 1.62 to $25 \%$ for the portions of available NDF and consumed NDF, because the composition of the ingested diet often differs from that available. This occurs due to the great selection capacity performed by goats, in addition, it can also be explained by the characteristic of the foods used in this experiment, which both had a lot of fiber (hay) and little (Spineless cactus). Data on the intake of NDF are important because it has a strong relationship with dry matter intake and energy availability, since fermentation and the rate of passage of this fraction through the rumen-reticulum is slower than other dietary constituents, providing a greater residence time and greater filling effect (Van Soest, 1994). 


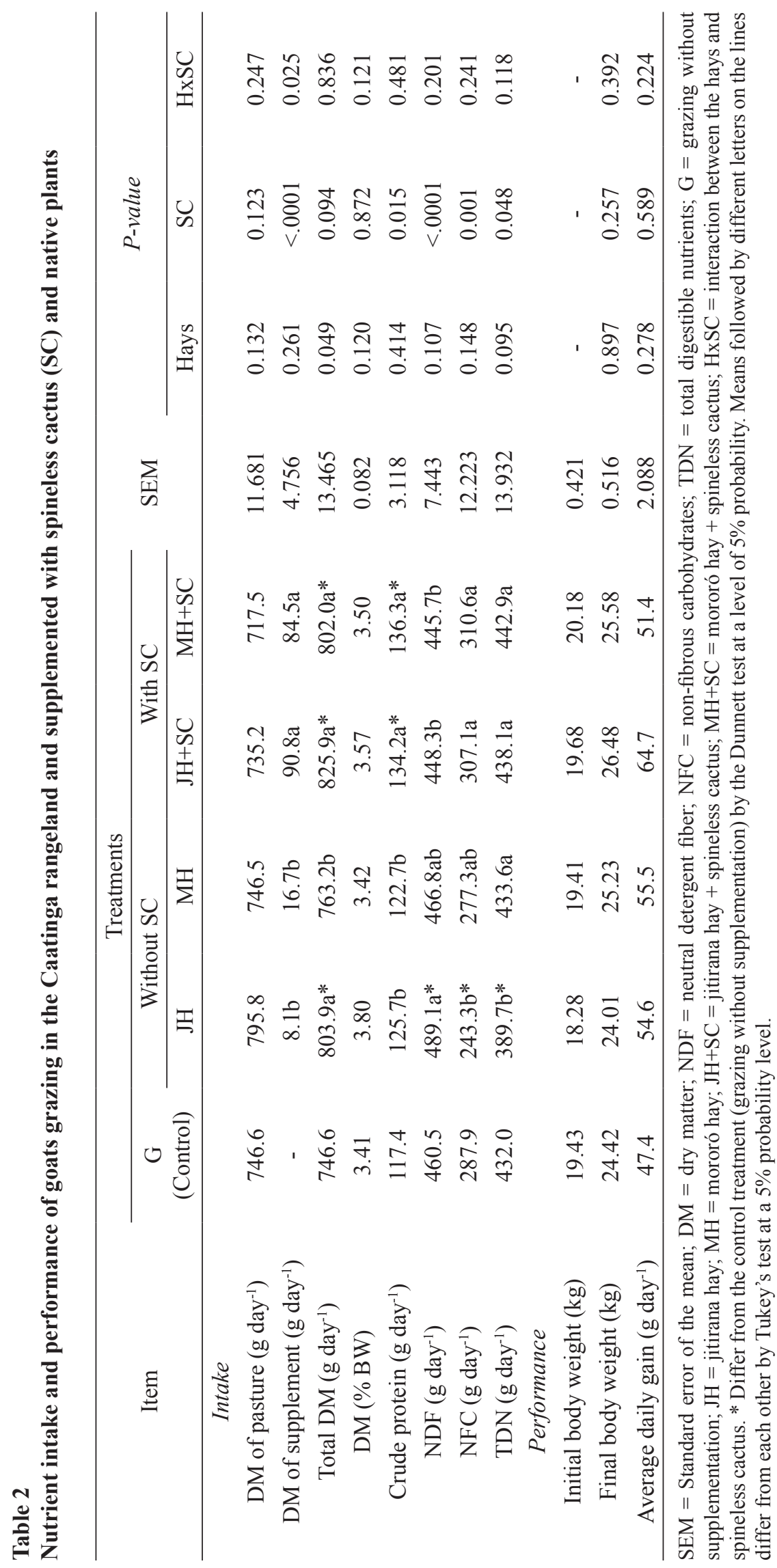


There was no difference $(\mathrm{P}>0.05)$ between diets of dry matter (DM) intake from pasture $\left(\mathrm{kg}\right.$ day $^{-1}$ and $\% \mathrm{BW} \mathrm{g} \mathrm{kg}{ }^{-1}$, Table 2). The absence of effects of the diets on the intake of DM from pasture can be explained by the quality represented by the extrusion, indicating that possibly there was selection by the animals of the most nutritious parts of the plants of the Caatinga (Table 1). This was possibly because during the months of the experiment, the occurrence of atypical rains was verified for the region, which provided a better development of native vegetation, and consequently a greater supply of forage.

Final body weight (PCF) and average daily gain (ADG) did not differ between treatments $(\mathrm{P}>0.05)$, with average weights of $25.1 \mathrm{~kg}$ and $54.7 \mathrm{~g}$ day1, respectively (Table 2). The National Research Council [NRC] (2007) predicts intakes of 620, 86.0, and $420 \mathrm{~g}$ of DM, CP of TDN, respectively, for animals with $20 \mathrm{~kg}$ and ADG of $100 \mathrm{~g}$. The animals in this experiment consumed an average of 788, 127, and $427.3 \mathrm{~g}$ day $^{-1}$ of DM, CP of TDN, respectively, thus demonstrating that the required consumption was achieved, except for animals supplemented with jitirana hay, in which the TDN intake was lower than recommended. However, for all treatments, the ADG was lower than estimated by the committee and the maximum weight gain achieved was $64.7 \mathrm{~g} \mathrm{day}^{-1}$.

Although the consumption of CP was reached in all treatments, and the highest intake of CP occurred in goats supplemented with jitirana and mororó hays with spineless cactus, the presence of secondary compounds in Caatinga plants should be considered, which have effects antinutritionals reducing the use of nitrogen. One of these compounds is the tannin found in several species of this vegetation (Santos et al., 2017). In research using tanniferous plants from the Caatinga biome, Vitti et al. (2005) observed a reduction in the digestibility of CP by sheep. At the same time, part of this protein may be attached to the fiber, reducing the access of ruminal microorganisms (M. J. S. Silva et al., 2017).

In addition, although the nutrient intakes reached values higher than those recommended by the NRC, and yet performance was not met, this committee is based on studies with different animals in the region and also in other environments that do not match the reality of the present study. Here, the need to relativize the data presented in the NRC for tropical breeding environments is highlighted.

There was no influence of treatments $(\mathrm{P}>0.05)$ on body weight at slaughter (BWS), empty body weight (EBW), hot and cold carcass weights, as well as their yields, biological yield, cooling losses, Longissimus muscle area $\left(\mathrm{cm}^{2}\right)$, finish, and conformation (Table 3). The similarity in the results of the performance variables contributes to the BWS, and the hot and cold carcass weights are not influenced by the treatments, which associated to the same age, probably contributed so that the carcass yields were not influenced by the treatments, once that, according to Cezar and Sousa (2007), among the factors inherent to animals, live weight and age are probably the ones that most influence carcass yields. The hot and cold carcass yields observed in the present study were close to those found by Bezerra et al. (2012) when supplementing goat grazing in the Caatinga. 


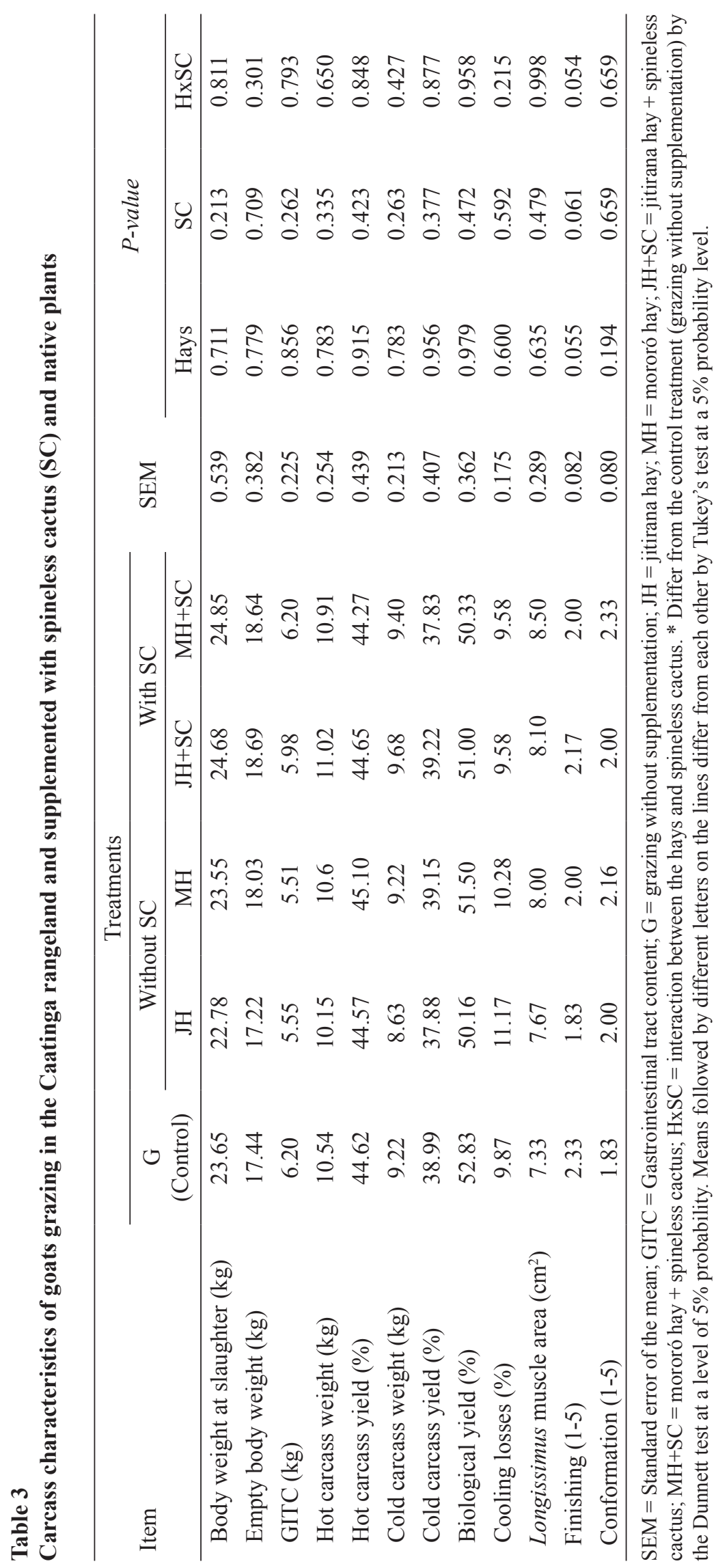

Semina: Ciências Agrárias, Londrina, v. 41, n. 5, p. 1639-1652, set./out. 2020 
The cooling losses were possibly not influenced by the fact that the carcasses did not present differences in the degree of finishing, that is, the amount of covering fat on the carcass, since the fat acts as a thermal insulator, consequently a similar cooling loss occurred between treatments. In addition, the deposition of body fat was greater around the internal organs, a characteristic peculiar to goats (Brand, Van der Merwe, Swart, \& Hoffman, 2019). Especially in goats of with no defined breed due to adaptive issues throughout its evolution.

The carcass morphometric measurements did not differ between treatments $(\mathrm{P}>0.05$; Table 4$)$, as well as the weights and yields of the meat cuts (Table 5). Even though there was a difference in the intake of supplements and in the intake of total $\mathrm{DM}$, this increase was not enough to imply greater synthesis and deposition of muscle tissue. Since the absolute weights and yields of commercial cuts were not influenced, this was probably also caused by the similarity of the animals' body weight at slaughter and their uniformity in terms of body size. According to Osório, Osório, Oliveira and Siewerdt (2002), when the carcass weight increases in absolute value, the weights of commercial cuts also increase, with a direct dependency relationship.

\section{Table 4}

Carcass morphometric measurements of goats grazing in the Caatinga rangeland and supplemented with spineless cactus (SC) and native plants

\begin{tabular}{|c|c|c|c|c|c|c|c|c|c|}
\hline \multirow{3}{*}{ Item } & \multicolumn{5}{|c|}{ Treatments } & \multirow{3}{*}{ SEM } & \multirow{2}{*}{\multicolumn{3}{|c|}{$P$-value }} \\
\hline & \multirow{2}{*}{$\begin{array}{c}\mathrm{G} \\
\text { (Control) }\end{array}$} & \multicolumn{2}{|c|}{ Without SC } & \multicolumn{2}{|c|}{ With SC } & & & & \\
\hline & & $\mathrm{JH}$ & MH & $\mathrm{JH}+\mathrm{SC}$ & $\mathrm{MH}+\mathrm{SC}$ & & Hays & $\mathrm{SC}$ & $\mathrm{HxSC}$ \\
\hline Internal carcass length $(\mathrm{cm})$ & 59.67 & 60.83 & 59.83 & 61.92 & 60.92 & 0.565 & 0.437 & 0.399 & 0.973 \\
\hline External carcass length $(\mathrm{cm})$ & 48.16 & 51.91 & 51.08 & 51.25 & 49.67 & 0.438 & 0.268 & 0.338 & 0.727 \\
\hline Hind width $(\mathrm{cm})$ & 12.08 & 12.17 & 12.5 & 13.17 & 13.0 & 0.126 & 0.772 & 0.156 & 0.389 \\
\hline Hind perimeter $(\mathrm{cm})$ & 47.50 & 47.00 & 45.42 & 47.42 & 47.08 & 0.449 & 0.382 & 0.343 & 0.566 \\
\hline Thoracic width $(\mathrm{cm})$ & 17.83 & 17.00 & 17.58 & 18.17 & 17.91 & 0.279 & 0.786 & 0.231 & 0.500 \\
\hline Thoracic depth (cm) & 25.00 & 26.00 & 24.58 & 28.1 & 29.75 & 0.931 & 0.974 & 0.127 & 0.493 \\
\hline Thoracic perimeter $(\mathrm{cm})$ & 62.6 & 59.2 & 61.2 & 64.0 & 62.4 & 0.416 & 0.817 & 0.102 & 0.057 \\
\hline Leg perimeter $(\mathrm{cm})$ & 28.75 & 29.17 & 28.42 & 29.52 & 28.5 & 0.286 & 0.247 & 0.895 & 0.999 \\
\hline $\mathrm{CCI}(\mathrm{cm})$ & 0.16 & 0.15 & 0,16 & 0,16 & 0,16 & 0.003 & 0.539 & 0.392 & 0.274 \\
\hline
\end{tabular}

$\mathrm{SEM}=$ Standard error of the mean $\mathrm{CCI}=$ carcass compactness index; $\mathrm{G}=$ grazing without supplementation, $\mathrm{JH}=\mathrm{jitirana}$ hay; $\mathrm{MH}$ $=$ mororó hay; $\mathrm{JH}+\mathrm{SC}=$ jitirana hay + spineless cactus; $\mathrm{MH}+\mathrm{SC}=$ mororó hay + spineless cactus; $\mathrm{HxSC}=$ interaction between the hays and spineless cactus; * Differ from the control treatment (grazing without supplementation) by the Dunnett test at a level of $5 \%$ probability. Means followed by different letters on the lines differ from each other by Tukey's test at a 5\% probability level.

The physical-chemical parameters of the meat: $\mathrm{pH}$, cooking losses, and shear force were not influenced $(\mathrm{P}<0.05)$ by the diets, with average values of 5.8, 25.75\%, and $3.04 \mathrm{kgf}$, respectively (Table 6). The cooking losses were probably not influenced because there was no effect of the diets on the final $\mathrm{pH}$ of the meat, which in this study ranged from 5.5 to 6.0. The $\mathrm{pH}$ values found in this research were close to those observed in the literature for the goat species (Monte, Selaive-Villarroel, Garruti, Zapata, \& Borges, 2007; Silva, Guim, Santos, Maciel, \& Soares, 2015). According to Gomide, Ramos and Fontes (2013), the final $\mathrm{pH}$ has a great influence on the quality of the meat, affecting its appearance, conservation, nutritional value, sensory attributes, and technological properties. 
Table 5

Weights and yields from commercial cuts of goats grazing in the Caatinga rangeland and supplemented with spineless cactus (SC) and native plants

\begin{tabular}{|c|c|c|c|c|c|c|c|c|c|}
\hline \multirow{3}{*}{ Item } & \multicolumn{5}{|c|}{ Treatments } & \multirow{3}{*}{ SEM } & \multirow{2}{*}{\multicolumn{3}{|c|}{$P$-value }} \\
\hline & \multirow{2}{*}{$\begin{array}{c}\mathrm{G} \\
\text { (Control) }\end{array}$} & \multicolumn{2}{|c|}{ Without SC } & \multicolumn{2}{|c|}{ With SC } & & & & \\
\hline & & $\mathrm{JH}$ & $\mathrm{MH}$ & $\mathrm{JH}+\mathrm{SC}$ & $\mathrm{MH}+\mathrm{SC}$ & & Hays & $\mathrm{SC}$ & $\mathrm{HxSC}$ \\
\hline \multicolumn{10}{|l|}{ Weight (kg) } \\
\hline Neck & 0.93 & 0.84 & 0.89 & 1.02 & 0.96 & 0.025 & 0.873 & 0.071 & 0.400 \\
\hline Shoulder & 2.02 & 1.90 & 1.98 & 2.11 & 2.06 & 0.049 & 0.879 & 0.200 & 0.579 \\
\hline Ribs & 1.20 & 1.29 & 1.41 & 1.36 & 1.17 & 0.039 & 0.690 & 0.343 & 0.107 \\
\hline Saw & 1.18 & 1.03 & 1.06 & 1.16 & 1.15 & 0.040 & 0.952 & 0.250 & 0.844 \\
\hline Loin & 0.80 & 0.89 & 0.85 & 0.82 & 0.84 & 0.028 & 0.639 & 0.960 & 0.824 \\
\hline Leg & 3.10 & 2.89 & 3.03 & 3.22 & 3.22 & 0.076 & 0.660 & 0.143 & 0.695 \\
\hline \multicolumn{10}{|l|}{ Yield (\%) } \\
\hline Neck & 10.16 & 10.00 & 9.66 & 10.50 & 10.33 & 0.167 & 0.528 & 0.088 & 0.892 \\
\hline Shoulder & 21.83 & 22.00 & 21.33 & 21.66 & 21.83 & 0.148 & 0.510 & 0.704 & 0.308 \\
\hline Ribs & 13.16 & 14.83 & 15.33 & 14.00 & 12.50 & 0.289 & 0.494 & 0.160 & 0.195 \\
\hline Saw & 12.66 & 11.83 & 11.50 & 11.83 & 12.16 & 0.235 & 0.674 & 0.635 & 0.541 \\
\hline Loin & 8.66 & 8.33 & 9.33 & 8.50 & 8.83 & 0.115 & 0.466 & 0.063 & 0.484 \\
\hline Leg & 33.50 & 33.66 & 32.83 & 33.33 & 34.17 & 0.309 & 0.895 & 0.533 & 0.221 \\
\hline
\end{tabular}

$\mathrm{SEM}=$ Standard error of the mean; $\mathrm{G}=$ grazing without supplementation; $\mathrm{JH}=$ jitirana hay; $\mathrm{MH}=$ mororó hay; $\mathrm{JH}+\mathrm{SC}=$ jitirana hay + spineless cactus; $\mathrm{MH}+\mathrm{SC}=$ mororó hay + spineless cactus; HxSC $=$ interaction between the hays and spineless cactus.

* Differ from the control treatment (grazing without supplementation) by the Dunnett test at a level of 5\% probability. Means followed by different letters on the lines differ from each other by Tukey's test at a $5 \%$ probability level.

Table 6

Physical-chemical parameters of meat from goats grazing in the Caatinga rangeland and supplemented with spineless cactus (SC) and native plants

\begin{tabular}{|c|c|c|c|c|c|c|c|c|c|}
\hline \multirow{3}{*}{ Item } & \multicolumn{5}{|c|}{ Treatments } & \multirow{3}{*}{ SEM } & \multirow{2}{*}{\multicolumn{3}{|c|}{ P-value }} \\
\hline & \multirow{2}{*}{$\begin{array}{c}\mathrm{G} \\
\text { (Control) }\end{array}$} & \multicolumn{2}{|c|}{ Without SC } & \multicolumn{2}{|c|}{ With SC } & & & & \\
\hline & & $\mathrm{JH}$ & $\mathrm{MH}$ & $\mathrm{JH}+\mathrm{SC}$ & $\mathrm{MH}+\mathrm{SC}$ & & Hays & $\mathrm{SC}$ & $\mathrm{HxSC}$ \\
\hline $\mathrm{pH}$ & 6.00 & 5.50 & 6.00 & 6.00 & 5.50 & 0.155 & 0.801 & 0.802 & 0.058 \\
\hline Cooking loss (\%) & 25.80 & 27.74 & 24.81 & 26.05 & 24.34 & 0.474 & 0.099 & 0.390 & 0.458 \\
\hline $\mathrm{SF}\left(\mathrm{kgf} \mathrm{cm}^{2-1}\right)$ & 3.00 & 2.80 & 3.40 & 2.90 & 3.10 & 0.118 & 0.198 & 0.662 & 0.411 \\
\hline L* (lightness) & 31.10 & 30.00 & 30.50 & 30.40 & 29.2 & 0.577 & 0.762 & 0.732 & 0.453 \\
\hline $\mathrm{a}^{*}$ (redness) & 9.74 & 9.87 & 10.29 & 9.67 & 10.54 & 0.207 & 0.196 & 0.959 & 0.644 \\
\hline $\mathrm{b}^{*}$ (yellowness) & 6.53 & $5.13 d^{*}$ & $6.25 \mathrm{~b}^{*}$ & $5.33 \mathrm{c}^{*}$ & $6.88 \mathrm{a}^{*}$ & 0.235 & 0.017 & 0.433 & 0.674 \\
\hline
\end{tabular}

$\mathrm{SEM}=$ Standard error of the mean; $\mathrm{SF}=$ shear force; $\mathrm{G}=$ grazing without supplementation, $\mathrm{JH}=$ jitirana hay; $\mathrm{MH}=\mathrm{mororó}$ hay; $\mathrm{JH}+\mathrm{SC}=$ jitirana hay + spineless cactus; $\mathrm{MH}+\mathrm{SC}=$ mororó hay + spineless cactus; HxSC = interaction between the hays and spineless cactus; * Differ from the control treatment (grazing without supplementation) by the Dunnett test at a level of 5\% probability. Means followed by different letters on the lines differ from each other by Tukey's test at a $5 \%$ probability level. 
According to Monte et al. (2007), among the factors that affect a decline in $\mathrm{pH}$ are gender, species, breed, age, nutritional status, pre-slaughter stress, and cooling temperature. Since the animals were all male goats castrated and slaughtered at the same age, this variable was not influenced even if the animals were fed different diets, however the nutritional intake was similar.

The variable that accurately reflects the characteristic of tenderness (shear force), the meat of the animals under study being considered soft according to the classification proposed by Cezar and Souza (2007). The average shear force value of $3.04 \mathrm{kgf} \mathrm{cm}^{2-1}$ deserves special mention, as this is a characteristic that can be well explored in the production systems of goats grazing in the Caatinga, adding value to the product.

There were differences $(\mathrm{P}<0.05)$ between diets for parameter $\mathrm{b}^{*}$ (yellowness), with all supplements differing from the control treatment (pasture without supplementation), with a higher value observed for the meat of animals supplemented with mororó hay associated with spineless cactus (Table 6). The parameters lightness $\left(\mathrm{L}^{*}\right)$ and redness $\left(\mathrm{a}^{*}\right)$ were not influenced by the treatments, with mean values of 30.24 and 10.02, respectively (Table 6). These were probably not influenced because the final $\mathrm{pH}$ of the meat was also not altered by the diets, since it has a direct relationship with the color of the meat (Gomide et al., 2013). The color of the meat can be influenced by the age of the animal, breeding system, feed, slaughter weight, and type of muscle (Martínez-Cerezo, Sañudo, Panea, \& Olleta, 2005; Ricardo et al., 2015). As the first aspect observed when choosing meat (Osório, Osório, \& Sañudo, 2009), it is decisive for its commercialization.

\section{Conclusions}

Supplementation with spineless cactus and mororó and jitirana hays did not improve the performance and carcass characteristics of goats raised on pasture in the Caatinga.

\section{Acknowledgments}

The authors thank the Coordenação de Aperfeiçoamento de Pessoal de Nivel Superior (CAPES) for granting a postgraduate scholarship (Master's degree) and the Conselho Nacional de Desenvolvimento Cientifico e Tecnológico (CNPq) for funding this research.

\section{References}

Abdalla, A. L., Fo., Corrêa, P. S., Lemos, L. N., Dineshkumar, D., Issakowicz, J., Ieda, E. H.,... Louvandini, H. (2017). Diets based on plants from Brazilian Caatinga altering ruminal parameters, microbial community and meat fatty acids of Santa Inês lambs. Small Ruminant Research, 154(9), 7077. doi: 10.1016/j.smallrumres.2017.07.005

Association of Official Analytical Chemists (1997). Official Methods of Analysis (16nd ed.). Gaithersburg, MD: AOAC.

Bezerra, S. B. L., Véras, A. S. C., Silva, D. K. A., Ferreira, M. A., Pereira, K. P., Santos, G. R. A.,... Almeida, O. C. (2012). Morphometry and carcass characteristics of goats submitted to grazing in the Caatinga. Revista Brasileira de Zootecnia, 41(1), 131-137. doi: 10.1590/S1516-35982012000100020

Brand, T. S., Van der Merwe, D. A., Swart, E., \& Hoffman, L. C. (2019). The effect of finishing period and dietary energy content on the carcass characteristics of Boer goats. Small Ruminant Research, 174(5), 110-117. doi: 10.1016/j.smallrumres.2019.03.012

Cezar, M. F., \& Sousa, W. H. (2007). Carcaças ovinas e caprinas: obtenção, avaliação e classificação. Uberaba: Editora Agropecuária Tropical.

Gomide, L. A. M., Ramos, E. M., \& Fontes, P. R. (2013). Ciência e qualidade da carne: fundamentos. Viçosa, MG: Editora UFV.

Gusha, A, J., Halimani, T. E., Katsande, S., \& Zvinorova, P. I. (2015). The effect of Opuntia ficus indica and forage legumes based diets on goat productivity in smallholder sector in Zimbabwe. Small Ruminant Research, 125(4), 21-25. doi: 10.1016/j. smallrumres.2015.02.018

Hall, M. B., Hoover, W. H., Jennings, J. P., \& Webster, T. K. M. (1999). A method for partitioning neutral detergent soluble carbohydrates. Journal of the Science of Food and Agriculture, 79(15), 2079-2086. doi: 10.1002/ (SICI) 1097-0010(199912)79:15<2079::AIDJSFA502>3.0.CO;2-Z 
Instrução Normativa n. 3; de 17 de Janeiro de 2000. Regulamento técnico de métodos de insensibilização para o abate humanitário de animais de açougue. Diário Oficial da União, Brasília, 24 jan. 2000, Seção I. p. 14-16. Retrieved from https://www. agricultura.gov.br/assuntos/sustentabilidade/bemestar-animal/ arquivos/arquivos-legisla cao/in-03de-2000.pdf

Lacerda, M. A., Silva, R. A., Linhares, P. C. F., Maracajá, P. B., \& Pinto, M. S. C. (2015). Potencial forrageiro da jitirana (Merremia Aegyptia) para a produção de feno no semiárido nordestino. Revista Agropecuária Cientifica no Semiárido, 11(1), 44-52. doi: 10.30969/ acsa.v11i1.609

Martínez-Cerezo, S., Sañudo, C., Panea, B., \& Olleta, J. L. (2005). Breed, slaughter weight and ageing time effects on consumer appraisal of three muscles of lamb. Meat Science, 69(4), 795-805. doi: 10.1016/j. meatsci.2004.11.013

Monte, A. L., Selaive-Villarroel, A. B., Garruti, D. S., Zapata, J. F. F., \& Borges, A. S. (2007). Parâmetros físicos e sensoriais de qualidade da carne de cabritos mestiços de diferentes grupos genéticos. Ciência e Tecnologia de Alimentos, 27(2), 233-238. doi: 10.1590/S0101-20612007000200004

National Research Council (2007). Nutrient requeriments of small ruminants: sheep, goats, cervids and New World camelids. Washington: National Academies Press.

Osório, J. C. S., Osório, M. T. M., \& Sañudo, C. (2009). Características sensoriais da carne ovina. Revista Brasileira de Zootecnia, 38(12), 292-300. doi: 10.1590/S1516-35982009001300029

Osório, J. C. S., Osório, M. T. M., \& Sañudo, C. (2009). Características sensoriais da carne ovina. Revista Brasileira de Zootecnia, 38(Esp.), 292-300. doi: 10.1590/S1516-35982009001300029

Pereira, J. M., Fº, Silva, A. M. A., \& Cézar, M. F. (2013). Manejo da Caatinga para produção de caprinos e ovinos. Revista Brasileira de Saúde e Produção Animal, 14(1), 77-90. doi: 10.1590/S151999402013000100010

Pinto, J. S., F'., Cunha, M. V., Souza, E. J. O., Santos, M. V. F., Lira, M. A., Moura, J. G.,... Silva, C. S. (2019). Performance, carcass features, and non-carcass components of sheep grazed on Caatinga rangeland managed with different forage allowances. Small Ruminant Research, 174(5), 103-109. doi: 10.1016/j. smallrumres.2019.03.010
Ricardo, H. A., Fernandes, A. R. M., Mendes, L. C. N., Oliveira, M. A. G., Protes, V. M., Scatena, E. M.,... Alves, L. G. C. (2015). Carcass traits and meat quality differences between a traditional and an intensive production model of market lambs in Brazil: Preliminary investigation. Small Ruminant Research, 130(9), 141-145. doi: 10.1016/j. smallrumres.2 015.07.007

Saliba, E. O. S., Faria, E. P., Rodriguez, N. M., Moreira, G. R., Sampaio, I. B. M., Saliba, J. S.,... Borges, A. L. C. (2015). Use of Infrared Spectroscopy to Estimate Fecal Output with Marker Lipe ${ }^{\circledR}$. International Journal of Food Science, Nutrition and Dietetics, 4(9), 1-10. doi: 10.19070/2326-3350-SI04001

Santos, K. C., Magalhães, A. L. R., Silva, D. K. A., Araújo, G. G. L., Fagundes, G. M., Ybarra, N. G., \& Abdalla, A. L. (2017). Nutritional potential of forage species found in Brazilian Semiarid region. Livestock Science, 195(1), 118-124. doi: 10.1016/j. livsci.2016.12.002

Statistical Analysis System Institute (2003). User's guide. Version 9.1. Cary, NC: SAS Institute Inc.

Silva, D. C., Guim, A., Santos, G. R. A., Maciel, M. I. S., \& Soares, L. F. P. (2015). Levels of feed supplementation on the qualitative aspects of meat from crossbred goats finished on caatinga. Revista Ciência Agronômica, 46(4), 855-864. doi: 10.5935/1806-6690.20150074

Silva, D. C., Guim, A., Santos, G. R. A., Souza, E. J. O., Urbano, S. A., Mesquita, F. L. T., \& Lafayette, E. A. (2016). Intake and digestibility of crossbred goats finished on caatinga grassland receiving feed supplementation during dry season. Revista Brasileira de Saúde e Produção Animal, 17(3), 484496. doi: 10.1590/S1519-99402016000300014

Silva, M. J. S., Silva, D. K. A., Magalhães, A. L. R., Pereira, K. P., Silva, E. C. L., Cordeiro, F. S. B.,... Santos, K. C. (2017). Influence of the period of year on the chemical composition and digestibility of pasture and fodder selected by goats in caatinga. Revista Brasileira de Saúde e Produção Animal, 18(3), 402416. doi: 10.1590/s1519-99402017000300001

Siqueira, M. C. B., Ferreira, M. A., Monnerat, J. P. I. S., Silva, J. L., Costa, C. T. F., Conceição, M. G.,... Melo, T. T. B. (2017). Optimizing the use of spineless cactus in the diets of cattle: total and partial digestibility, fiber dynamics and ruminal parameters. Animal Feed Science and Technology, 226(3), 56-64. doi: 10.1016/j.anifeedsci.2016.12.006 
Sniffen, C. J., O’Connor, J. D., Van Soest, P. J., Fox, D. G., \& Russell, J. B. (1992). A net carbohydrate and protein system for evaluating cattle diets: II. Carbohydrate and protein availability. Journal of Animal Science, 70(11), 3562-3577. doi: $10.2527 / 1992.70113562 \mathrm{x}$

Van Soest, P. J., Robertson, J. B., \& Lewis, B. A. (1991). Methods for dietary fiber, neutral detergent fiber, and nonstarch polysaccharides in relation to animal nutrition. Journal of Dairy Science, 74(10), 35833597. doi: 10.3168/jds.S0022-0302(91)78551-2

Van Soest, P. J. (1994). Nutritional ecology of the ruminant. New York: Cornell University Press.
Vitti, D. M. S. S., Abdalla, A. L., Bueno, I. C. S., Silva, J. C., F ${ }^{o}$., Costa, C., Bueno, M. S.,... Mueller-Harvey, I. (2005). Do all tannins have similar nutritional effects? A comparison of three Brazilian fodder legumes. Animal Feed Science and Technology, 119(3-4), 345-361. doi: 10.1016/j.anifeedsci.2004. 06.004

Wheeler, T. T., Cundiff, L. V., \& Koch, R. M. (1993). Effects of marbling degree on palatability and caloric content of beef. Beef Research - Progress Report, 71(4), 133-134. Retrieved from http://digital commons.unl.edu/hruskareports. 